Journal of Universal History Studies (JUHIS) • 2(1) • June・2019・pp. 1-18

\title{
Kilis Günlük Halk Gazetesindeki Haberlere Göre Hatay Meselesi ${ }^{1}$
}

\author{
Nermin Zahide Aydın ${ }^{2}$ \\ Kilis 7 Aralk University, Assistant Professor, Muallim Rifat Faculty Of Education, Kilis, Turkey \\ Received- Accepted: 07.01.2019-13.02.2019 \\ Research Article
}

Öz

Birinci Dünya Savaşı'nın sonunda Osmanlı Devleti’nin toprakları işgal edilmiştir. Savaş bitmeden önce İngiltere ve Fransa kendi aralarında yaptıkları anlaşma ile Anadolu'nun güneyini paylaşmışlardır. Anadolu'nun güneyinde yer alan İskenderun ve Antakya bölgesi, tarih boyunca stratejik öneme sahip olmuştur. Bu nedenle Fransa Hatay’ 1 işgal etmiş, bölgede etkili olmak için çeşitli yatırımlar yapmıştır. Türkiye ise ülke içinde ve dışında Hatay konusunda büyük mücadele vermiștir. Mustafa Kemal, 1923 yllından itibaren bölgenin anavatana katılması için yoğun bir şekilde çalışmaya başlamış ve Tayfur Sökmen'le arkadaşlarını bölgede teşkilatlanmaları için görevlendirmiştir. Mustafa Kemal'in çalışmaları sonucunda Hatay anavatana katılmıştır. Hatay'ın anavatana katılma süreci yerli ve yabancı basında geniş yer bulmuştur. Bu çalışmada Hatay meselesinin ortaya çıkşından, Hatay’ın anavatana katılmasına kadar olan süreçte yaşanan gelişmelerin Kilis Günlük Halk Gazetesinde yer alan haberler doğrultusunda incelenmesi hedeflenmiştir.

Anahtar Kelimeler: Hatay, Kilis Günlük Halk Gazetesi.

\section{The Hatay Questıon Accordmg To News In Kilis Daily Newspaper}

\begin{abstract}
At the end of World War I, the lands of the Ottoman Empire were occupied. Before the war ended, Britain and France shared the southern part of Anatolia with their agreement. Iskenderun and Antakya region located in the south of Anatolia have been of strategic importance throughout history. For this reason, France has invaded to Hatay and made various investments to be effective in the region. Turkey has fought for Hatay inside and outside the country. Since 1923, Mustafa Kemal has been working intensively to join the homeland of the region and Atatürk assigned Tayfur Sökmen and his friends to organize in the region. As a result of the work of Mustafa Kemal Hatay joined the motherland. The accession period of Hatay to homeland has found wide place in the domestic and foreign press. In this study, the developments in the process from the emergence of the Hatay issue to the attachment of Hatay to the motherland will be examined according to the news in Kilis Daily Newspaper.
\end{abstract}

Keywords: Hatay, Kilis Daily Newspaper.

\footnotetext{
${ }^{1}$ This article is analyzed by two reviewers and it is screened for the resembalance rate by the editor. (Bu makale iki hakem tarafindan incelenmiş ve editör tarafindan benzerlik oranı taramasından geçirilmiştir)

${ }^{2}$ nzahideaydin@hotmail.com, ORCID:0000-0001-7772-6764.
} 
Kilis Günlük Halk Gazetesindeki Haberlere Göre Hatay Meselesi/Nermin Zahide AYDIN

\section{Giriş}

Hatay ve çevresi, Osmanlı döneminde İskenderun Sancağı olarak adlandırılmıştır. Hatay'ın Akdeniz yolu ile Avrupa ve Afrika'ya açılan bir liman kenti olması (Karakoç, 2009, s. 98), verimli topraklara sahip olması ve transit geçiş yolları üzerinde bulunması Avrupa ülkelerinin dikkatini çekmiştir (Akçora, 2000, s. 327). Hatay'da bulunan ve doğal liman olan İskenderun Limanı da bölgenin önemini arttırmıştır (Dayı, 2001, s. 12).

Birinci Dünya Savaşı devam ederken Fransa ve İngiltere, 16 Mayıs 1916 tarihinde Sykes-Picot Anlaşması'nı imzalamıştır. Anlaşmaya göre Suriye, Lübnan, Çukurova ve Sancak Bölgesi, Fransa'nın nüfuz bölgesine dâhil edilmiştir. İtilaf Devletleri, Birinci Dünya Savaşı'ndan sonra 30 Ekim 1918 tarihinde imzalanan Mondros Mütarekesi'nin 7. ve 16. maddelerini ileri sürerek adı geçen yerleri işgal etmeye başlamıştır (Doğramacı, 2001, s. 12). Ateşkes Anlaşmasının 7. maddesi İtilaf Devletlerine güvenliklerini tehdit edecek bir durum ortaya çıktığında herhangi bir stratejik noktayı işgal etme hakkı tanırken 16. madde ile Yemen, Hicaz, Irak ve Suriye'deki Osmanlı birliklerinin en yakın kumandanlara teslimi öngörülmüştür.

\section{Hatay ve Yöresinin İşgali}

Fransız Yüksek Komiserliği tarafindan 27 Kasım 1918 tarihinde bir kararname çıkarılmıştır (Akçora, 2000, s. 329). Kararnameye göre Sancak bölgesinin yönetim şekli ve kurallarının, Yüksek Komiserlik tarafindan belirlenmesine karar verilmiştir (Tekin, 2009, s. 23). Fransa, 11 Aralık 1918 günü İskenderun Sancağın (Hatay) işgal etmiştir (Akçora, 2000, s. 330).

İşgalden yaklaşık altı ay sonra bir Amerikan heyeti İskenderun Sancağı’na gelerek orada yaşayanlara Fransız idaresinden memnun olup olmadıklarını sormuştur. Bunun üzerine Belen Kaymakamı Mürselzade İhsan Bey, Kadı Ali Rıza Efendi ve Şeyh Hasan Ağa Fransız işgaline karşı olduklarını ve Türk idaresini istediklerini belirtmişlerdir. Komisyonun yaptığı görüşmeler sonucunda Fransız idaresini isteyenlerin azınlıkta olduğunu tespit edilmiştir. Yaşanan bu gelişmeden sonra, bölgenin önemli şahsiyetleri, aralarındaki anlaşmazlıklara son vererek mücadele etme kararı almışlardır (Akçora, 2000, s. 331). Kısa bir süre sonra Antakya'da Müdafaai Hukuk Cemiyeti kurulmuştur (Kara, 2017, s. 121). Bölgenin Misak-1 Milli sınırları dışında olduğu ile ilgili söylentilerin yayılması üzerine 30 Mayıs 1920 tarihinde Tayfur Sökmen Bey tarafindan Ankara'da bulunan Mustafa Kemal Paşa'ya Antakya, İskenderun ve havalisinin Misak-1 Milli'ye dâhil olup olmadığını soran bir telgraf çekilmiştir (Tekin, 2009, s. 24). Mustafa Kemal Paşa “Türklerin yaşadığı her yer Misak-1 Milli'ye dâhildir' diyerek mücadeleye devam edilmesini istemiştir (Karakoç, 2009, s. 100). Mustafa Kemal Atatürk, bir süre önce de TBMM'nin açılışında yaptığı konuşmada Misak-1 Milli ile ilgili olarak şu açıklamalarda bulunmuştur (TBMMZC, D.1, C.1, İçtima Senesi.1, İkinci İçtima, 24.4.1336): "Hepinizin bildiği gibi, 10 Temmuz 1919 tarihinde Erzurum'da Doğu Anadolu illerini kapsayan bir milli kongre toplandı. Bu milli kongrenin koyduğu şartlar, sanırım bilinmektedir. Fakat şimdiye kadar yaptıklarımıza bir başlangıç sayıldığı için sizlere hatırlatmak üzere önemli noktaları yeniden okuyacağım. Erzurum kongresinin koyduğu şartlardan birincisi; I. Dünya Savaşının genel durumu gereğince, düşmüş olduğumuz yenilgi nedeniyle vatanımızın birçok önemli bölümü 
düşmanlarımızın istilâsı altına girmişti. Millet, bütün isteklerinde maddi ve gerçekçi düşünmek ve ancak kuvvet ve gücüyle sağlayacağı durumlarda kendine yeni bir sınır çizmek üzere idi. I̧şte kongre bu sınırı çizmiştir. Bu milli sınırın dostlukla korunması için demiştir ki, Ateşkes antlaşmasının imzalandığı 30 Ekim 1918 tarihinde çizilen hudut, sınırımız olacaktır. Vatanımızın sınırı olacak bu hududu, sanırım, ayrıntılarıyla bilmeyen arkadaşlarımız vardır. Yeniden fazla ayrıntıya girmek istemediğim için şu şekilde açıklayacağım. Doğu sınırını Kars, Ardahan ve Artvin'i içine alacak şekilde göz önüne getiriniz. Batı sınırı, bildiğiniz gibi, Edirne'den geçiyor. En büyük değişiklik güney sınırımızda olmuştur. Güney sınırımız İskenderun'un güneyinden başlar, Halep'le Kadıma arasında Cerablus köprüsünde sona eren bir hat ve doğu kısmı da Musul ili Süleymaniye ve Kerkük dolayı ve bu iki bölgeyi birbirinden ayıran hat. Efendiler, bu sınır sadece askeri gerekçelerle çizilmiş bir sınır değildir, milli sınırdır. Milli sınır olmak üzere tespit edilmiştir. Fakat bu sınır içinde İslam ögesine sahip yalnız bir milletin olduğu düşünülmesin. Bu sınır içinde Türk vardır, Çerkez vardır ve diğer İslam öğeleri vardır. İște bu sınır karışık bir halde yaşayan, bütün amacını tam anlamı ile birleştirmiş olan kardeş unsurların milli sınırıdır. Bu sınır olayını kararlaştıran maddenin içerisinde büyük bir ana öğe vardır. Fazla olarak da bu vatan hududu içinde yaşayan İslam unsurlarının her birinin kendine özgü olan yörelerine, geleneklerine, ırkına özel olan ayrıcalıkları bütün samimiyeti ile ve karşılıklı olarak kabul etmiş ve onaylanmıştı. Doğal olarak bununla ilgili ayrıntılı bilgiler yoktur. Çünkü bu ayrıntılı bilgilere girmenin zamanı değildir. İnşallah, varlığımız kurtarıldıktan sonra kesin şeklini alacağından şimdilik ayrıntıya girilmemiştir. Fakat aslında bu, maddenin kapsamındadır."

Milli mücadele devam ederken Yunan kuvvetlerinin I. İnönü Savaşı'nda yenilerek geri çekilmesi, İngiliz ve Fransız hükümetlerinde büyük bir şaşkınlığa neden olmuştur. Her iki ülke de sömürgelerini kaybetmemek için bir konferans düzenlemişler ve konferansa Osmanlı Devleti’ni, Yunanistan'1 ve Ankara'yl temsilen de bir adayın katılmasını istemişlerdir. Konferansa TBMM'ni temsilen Bekir Sami Bey, İstanbul'u temsilen de Sadrazam Tevfik Paşa katılmıştır. Bekir Sami Bey’e konferansa katılmadan önce "Hududu milliyemiz dâhilinde memleketimizin tamamiyetini ve milletin istiklali tanımını temin etmek" talimatı verilmiştir (Armaoğlu, Tarihsiz, s. 317-318). Türkiye ile Fransa arasında, 11 Mart 1920'de Londra'da Hariciye Vekili Bekir Sami Bey ile Fransız Dışişleri Bakanı Birand arasında yapılan görüşmede Türk unsuru fazla olan İskenderun Sancağının durumu ele alınmış fakat bir sonuç elde edilememiş, 25 Nisan 1920 tarihinde Müttefik Devletleri Yüksek Konseyi, Suriye ve Lübnan'ın yönetimini Fransa'ya bırakmıştır. Fransa 1 Eylül 1920'de Halep, Şam, Lübnan ve Alevi bölgesi olmak üzere dört yönetim birimi oluşturmuştur. İskenderun Sancağı ise özerkliği korunarak Halep'e bağlanmıştır (Tekin, 2009, s. 23-26).

Milli Mücadele sürerken kazanılan Sakarya Savaşı, İtilaf Devletleri arasındaki görüş ayrılığının artmasına neden olmuş ve bunun sonucu olarak da Fransa ile 20 Ekim 1921 tarihinde Ankara Anlaşması imzalanmıştır. Anlaşmanın 7. maddesiyle İskenderun Bölgesi için özel bir yönetim rejiminin kurulmasına karar verilmiştir (Üzgel, 2004, s. 149). Türk parası resmi resmi para birimi olmuş, Sancak halkının milli kültürlerinin korunması için her türlü kolaylığın sağlanması kararlaştırılmışır. Fakat Misak-1 Milli sınırlanı içinde olan Hatay, Ankara Anlaşması ile Türk hudutlarının dışında kalmıştır (Villalta, 1982, s. 689). Sancak halkı memnuniyetsizliklerinin iletilmesi için, Tayfur Sökmen Bey’i Ankara'ya göndermiştir (Tekin, 2009, s. 40). 
Mustafa Kemal Paşa, Tayfur Sökmen'i 2 Kasım 1921'de TBMM'de kabul etmiş ve “Şimdilik bir şey yapmadık. İnşallah ileride sizleri de kurtaracağız” diyerek Hataylilara moral vermek istemiştir (Mursaloğlu, 2001, s. 80).

Batı cephesinde kazanılan zaferlerden sonra Ankara Hükümeti, Sevr Anlaşmasına karşı çıkmıştır. Bunun üzerine Lozan'da bir konferans düzenlenmesi kararlaştırılmıştır. Konferansta Fransa ile yapılan görüşmelerde esas mesele borçlar olmasına rağmen diğer meseleler de görüşülmüsşür. Konferansta TürkiyeSuriye sınırının tespiti konusunda karma bir komisyon kurulması kararlaştırılmasına rağmen komisyon ancak 1925 yılında kurulabilmiştir. Türkiye'deki Fransız misyoner okulları da konferansta görüşülen konular arasında yer almıştır. Türk hükümeti bir yönetmelik hazırlayarak yabancı okullarda tarih ve coğrafya derslerinin Türk öğretmenler tarafindan Türkçe okutulmasını istemiştir. Fransa önce buna karşı çıksa da bu teklifi kabul etmek zorunda kalmıştır. Borçlar konusu ise çok şiddetli tartışmalara neden olmuştur. 13 Haziran 1928'de imzalanan anlaşmalarla ödenecek borcun miktarı ve ödeme şekli bir formüle bağlanmıştır. Fakat bir yıl sonra dünya ekonomik buhranın patlak vermesi üzerine yeni bir borç ödeme sözleşmesi yapılmıştır. Fransa ile anlaşmazlığa neden olan diğer bir sorun da Adana-Mersin demiryolunun satın alınması konusu olmuştur. Fransa, bir Fransız şirket tarafindan işletilen Adana-Mersin demiryolunu almak isteyen Türkiye’ye önce olumsuz cevap vermiş fakat sonunda satmaya razı olmuştur (Uçarol, Tarihsiz, s. 324-325). Türkiye’yi ilgilendiren bu sorunların çözümüne önem veren Mustafa Kemal, Sancak sorununun çözümü için Lozan Barış görüşmelerini bir firsat olarak görmüştür (Tekin, 2009, s. 51). Lozan görüşmelerinin kesildiği bir sırada 15 Mart 1923 tarihinde Adana’ya gelen Mustafa Kemal (Eroğlu, 1986, s. 130), yol kenarında kendisini karşılamak için bekleyen siyah giyinmiş Antakyalı genç bir kızın 'Paşam bizi de kurtar” diye yalvarması üzerine "40 asırlık Türk yurdu düşman eline bırakılamaz" şeklinde cevap vermiştir (Melek, 1986, s.34). Fakat 24 Temmuz 1923’te imzalanan Lozan Antlaşması bölgenin durumunda bir değişiklik getirmemiştir (Tekin, 2009, s. 53).

\section{Hatay Meselesinin Gündeme Gelmesi}

Lozan Anlaşması ile iki ülke arasındaki bütün sorunlar halledilememiștir. 8 Eylül 1936 tarihinde parafe edilen anlaşma ile Suriye'deki manda idaresinin son bulması öngörülmüş, ancak Sancağın durumundan söz edilmemiştir (Eroğlu, 1986, s. 131). Milletler Cemiyeti Konseyi’nin 2 Eylül 1936 tarihli toplantısında, Dışişleri Bakanı Tevfik Rüştü Aras, Sancak sorununun çözümü için Fransa'ya ikili görüşme teklif etmiştir. Ancak Fransız temsilci buna verdiği cevapta, Fransa ve Türkiye arasında bu konuda yapılacak görüşmelere Suriye Hükümetinin de katılması gerektiğini bildirmiştir (Gönlübol ve Sar, 1997, s. 132). 26 Eylül 1936 tarihinde Fransız temsilcisi, Milletler Cemiyeti'ne yaptığı açıklamada ülkesinin üç yıl sonra Suriye Cumhuriyeti’ne tam bağımsızlık tanımak üzere bir anlaşma yaptığını belirtmiş̦ir. Bunu duyan Türk delegesi kürsüye gelerek bu haberden memnunluk duyduğunu söylemiş, Fransız Hükümeti’nin aynı şekilde davranarak İskenderun Sancağını da eşit şartlardan yararlandıracağını umduğunu belirtmiştir(Villalta, 1982, s. 690-691).

Türkiye, Sancak ile ilgili olarak 6 Ekim 1936'da Milletler Cemiyeti'ne ve 9 Ekim 1936'da Fransa'ya birer nota vermiştir (Eroğlu, 1986, s. 131). Sancak bölgesine bağımsızlık verilmesi ile ilgili olarak verilen ilk 
notaya Fransa'nın verdiği cevap olumsuz olmuştur (Villalta, 1982, s. 691). Sancağa bağımsızlık vermenin Suriye'nin parçalanmasına neden olacağını bildiren Fransa'ya ikinci bir nota daha verilmiştir (Mursaloğlu, 2001, s. 82). Notada, Sancak'a verilecek muhtariyetin Suriye ile hiçbir ilgisinin bulunmadığı ifade edilmiştir (Tekin, 2009, s. 73). Fransa ise sorunu Milletler Cemiyeti'ne götürerek Türkiye ile uzlaşma yollarını aramayı tercih etmiştir (Sarınay, 2000, s. 365). Türkiye Fransa’nın bu teklifini kabul etmiştir (Yalçın, 2006, s. 308).

\section{Hatay Sorununun Milletler Cemiyeti'nde Görüşülmesi}

Türkiye ile Fransa'nın, sorunun Milletler Cemiyeti’nde görüşülmesine karar vermesi üzerine 14 Aralık 1936'da toplanan Milletler Cemiyeti (Yalçın, 2006, s. 308), İsveç temsilcisi Sandler’i Sancak sorunu için raportör tayin etmiştir. Sandler, 16 Aralık’ta meclise sunduğu raporunda Sancak bölgesine üç kişilik bir gözlemci heyet gönderilmesini, tarafların raportörle temas halinde görüşmeye devam etmesini ve konunun Miletler Cemiyeti’nin Ocak ayı toplantısında tekrar ele alınmasını tavsiye etmiştir (Sarınay, 2000, s. 371). 22 Aralık’ta Hollanda, Norveç ve İsviçre'den üç kişilik bir gözlemci heyet oluşturulmuştur. Meclisin kararı gereğince ikili görüşmelerde bulunmak üzere Tevfik Rüştü Aras, 21-22 Aralık 1936'da Paris'e gitmiştir. Fakat Fransa Hükümeti ile yapılan görüşmelerde olumlu bir sonuç alınamamıştır (Gönlübol ve Sar, 1997, s. 132-134).

Hatay'da Aralık 1936'da Türklere karşı provokatif olayların çıkması üzerine Türkiye, Beyrut başkonsolosu Feridun Cemal Erkin'i hadiseleri yerinde incelemek üzere görevlendirmiştir (Dağıstan ve Sofuoğlu, 2005, s.13). Sancak'ta başta Fransız delegesi olmak üzere Türk ve diğer grupların temsilcileri ile görüşen Erkin'in hazırladığı raporu, Mustafa Kemal incelemiş ve ilhak kararı almıştır (Karakoç, 2009, s. 102). Çok geçmeden 1936 yılında verdiği bir emirle Antakya-İskenderun havalisinin adını, bölgenin Türk kimliğine vurgu yapmak amacı ile Hatay olarak değiştirmiştir. Bundan sonra Sancak'a Hatay denmeye başlanmıştır (Kara, 2017, s. 122). Ocak ayında vefat eden Nuri Conker'e çok üzülen Mustafa Kemal 'Hatay'ın üzüntüsüne Conker'in üzüntüsü karıstı" (İnan, 2013, 415) diyerek meseleye verdiği önemi belirtmiştir. Mustafa Kemal 1937 yılının Ocak ayının ilk haftasında Konya ve Ulukışla'ya kadar seyahat ettikten sonra Ankara'ya dönmüş ve Hatay meselesinin görüşüldüğü Bakanlar Kurulu toplantısına başkanlık yapmıştır. Paris’te devam eden Türk-Fransız görüşmelerinde Türkiye'nin Hatay için bağımsızlık isteği Fransa tarafindan reddedilse de Mustafa Kemal'in güney gezisi Fransa'nın kararını gözden geçirmesine neden olmuştur (Sarınay, 2000, s. 369-371). Mustafa Kemal Atatürk, güney illerini kapsayan son gezisinde Hatay'la ilgili olarak Fransa'ya bir mesaj vermek istemiştir. Şevket Süreyya Aydemir, Mustafa Kemal Atatürk'ün Hatay davasına kendini verişini, bilinenden çok daha derin ve çok daha içli olduğunu belirtmiştir (Bozkurt, 2017, s. 104).

Fransız basını konu ile yakından ilgilenmiş ve basında Sancak meselesi ile ilgili yazılar yayınlanmıştır. 14 Aralık 1936 tarihli Qeuvre gazetesinde Mustafa Kemal'in Sancağın Suriye hâkimiyetine girmesini istemediği, aksine Milletler Cemiyeti'nin denetimi altında muhtar bir idare kurulmasını arzu ettiği yazılmıştır. Aynı tarihli Action Française gazetesinde ise, Mustafa Kemal'in İskenderun Sancağı hakkında ileri sürdügü iddiaların cesur ve idealist iddialar olduğu ileri sürülmüştür (Tekin, 2009, s. 76).

Milletler Cemiyeti’nin 20 Ocak 1937 tarihindeki toplantısına Dışişleri Bakanı Tevfik Rüştü Aras 
başkanlığında bir heyet müzakereci olarak gönderilmiş̧ir (Sarnay, 2000, s. 371). 27 Ocak 1937'de Türk ve Fransız Hükümetlerinin aralarnnda vardıkları anlaşmaya göre Hatay ile ilgili bir statü ve anayasanın hazırlanmasını içeren bir metin hazırlanmış ve Milletler Cemiyeti'nin sözcüsü tarafindan konseyin onayına sunulmuştur (Akçora, 2000, s. 343). Çok geçmeden Milletler Cemiyeti tarafindan Hatay için anayasa hazırlamak üzere bir komisyon kurulmuştur. Uzmanlar komitesi, 25 Şubat'ta Sancak'a gönderilen gözlemci heyet ile birlikte çalışmalarna başlamıştr (Gönlübol ve Sar, 1997, s. 136). Bu esnada Fransız elçisi tarafindan Türkiye, Fransa ve Suriye arasında imzalanacak üç taraflı anlaşma hakkında Türk hükümetine bir nota verilmiştir (Kilis Günlük Halk Gazetesi, 6.05.1937, s. 1). Türk Dışişleri Bakanı, Hatay meselesinin çözümü ile ilgili olarak Cenevre'ye (Kilis Günlük Halk Gazetesi, 10.05.1937, s. 1), diğer Türk yetkililer ise Paris'e gitmiş ve Fransiz devlet yetkilileri ile meselenin çözümüne yönelik görüşmeler yapmışlardır (Kilis Günlük Halk Gazetesi, 13.05.1937, s. 1). Suriye ise Türkiye'nin faaliyetlerine karşllk olmak üzere Hatay ile ilgili olarak Cenevre uzmanlar heyetine bir nota vermiş̧ir (Kilis Günlük Halk Gazetesi, 19.05.1937, s. 3). Çok geçmeden Hatay anayasası ve statüsü ile ilgili çalışmalara başlanmıştr (Kilis Günlük Halk Gazetesi, 24.05.1937, s. 1). Hatay anayasası ile statüsüne ait son kararlar, konseyin 28 Mayıs 1937 toplantısında Türkiye lehine bitmiş (Kilis Günlük Halk Gazetesi, 31.05.1937, s. 1) ve Milletler Cemiyeti Konseyi'nde Sancak'ın "ayrı bir varlık" olduğu hukuken kabul edilmiștir (Sarınay, 2000, s. 374). Akabinde yapılan prensip anlaşması Milletler Cemiyeti tarafindan onaylanmıştır (Karakoç, 2009, s. 104). Statü ve anayasanın 29 Kasım 1937 günü yürürlüğe girmesi öngörülmüștür (Sarınay, 2000, s. 374).

Hatay halkı Türk-Fransız anlaşmasını sevinç ile karşllamış (Kilis Günlük Halk Gazetesi, 03.06.1937, s. 1), Haziran ayında bayram yapılmasına karar verilmiştir (Kilis Günlük Halk Gazetesi, 14.06.1937, s. 1). Fakat bu anlaşma Sancak meselesini kökünden halledememiş̧ir. 1937 yllının yaz aylarında yeni bir takım güçlükler ortaya çıkmıştur (Gönlübol ve Sar, 1997, s. 137). Suriye Meclisi 3 Haziran 1937 tarihinde bir bildiri yayınlayarak yapılan anlaşma ile belirlenen statüyü tanımadığını açıklamış (Sarınay, 2000, s. 376) ve sınır boyundaki Türk ürünlerinden ağır vergiler almak istemiştir (Kilis Günlük Halk Gazetesi, 10.06.1937, s. 2). Halkın ürününü toplayamaması sonucunda ürünlerde pahalılık başlamıştır (Kilis Günlük Halk Gazetesi, 28.06.1937, s. 2). Sancak meselesi Milletler Cemiyeti'nde halledilmiş ve Suriye sınır ile ilgili anlaşmalar yapılmış olmasına rağmen yaşanan skkıntlar devam etmiştir (Kilis Günlük Halk Gazetesi, 21.06.1937, s. 2). Gerginliği azaltmak için Türk yetkililer tarafindan her iki milletin birbirlerinin ulusal duygularnna saygı göstererek dost geçinmeye mecbur olduklanı ifade edilmiştir (Kilis Günlük Halk Gazetesi, 24.06.1937, s. 2). Bu esnada Hatay'ın bağımsızlğının ilanı ile ilgili olarak Türk yetkililer ile Fransa'nın Ankara elçisi İstanbul'da görüşmüş̦ür (Kilis Günlük Halk Gazetesi, 01.07.1937, s. 1). Adana'da toplanan Türkiye-Suriye daimi muhtelit hudut komisyonu da çalışmalarına devam etmiş̧ir. Komisyonun Fransı heyeti reisi Philiph David, Türk heyeti reisi Tevfik Hadi için bir merasim düzenlemiş̧ir (Kilis Günlük Halk Gazetesi, 28.06.1937, s. 2). Kısa bir süre sonra Hatay'n istiklali ve yeni rejimin resmen ilan edilmesine karar verilmiştir (Kilis Günlük Halk Gazetesi, 05.07.1937, s. 1). Bunun üzerine bazı Hatay mebusları Suriye Meclisi'ne istifalarını göndermiştir (Kilis Günlük Halk Gazetesi, 19.07.1937, s. 1).

Suriye Başbakanının İstanbul'da Türk yetkilileri ile görüş̧mesinden sonra (Kilis Günlük Halk Gazetesi, 
08.07.1937, s. 1) Suriye'de yayın yapan bazı gazeteler, Türkiye-Suriye dostluğunun değerinden bahsetmeye başlamıştır (Kilis Günlük Halk Gazetesi, 05.05.1937, s. 2). Suriye hükümeti, Şam'da yayın yapan El-Kabes, ElEyyam ve El-Cezire gazetelerini mevcut sürecin bozulmaması için süresiz kapatmıștır (Kilis Günlük Halk Gazetesi, 22.07.1937, s. 2). Türkiye ile Suriye arasında bir dostluk anlaşması yapılmasına karar verilmiş, Suriye başbakanı herhangi bir sebeple yapılacak sokak gösterilerine engel olacağıı belirtmiştir (Kilis Günlük Halk Gazetesi, 12.08.1937, s. 1). Fakat görevi sona eren Fransız delegenin Hatay'dan ayrlmadan önce asılszz vergiler almak istemesi mevcut durumun bozulmasına neden olmuş̧ur. Amık Ovası'ndaki Arap aşiretler, Değirmenkaşı pazarını yağma etmiştir (Kilis Günlük Halk Gazetesi, 12.07.1937, s. 1). Bunun üzerine Dışişleri Bakanlı̆̆’ndan ilan edilen bir yazı ile güney bölgesinde emlakı olan Türklerin bir beyanname göndermeleri istenmiş̧ir. Bölgede yaşayan Türkler istenen bilgileri bir mektup ile ilgili kurumlara bildirmiş̧ir (Kilis Günlük Halk Gazetesi, 29.07.1937, s. 1). Kısa bir süre sonra Hatay Halkevi'ne saldırı düzenlenmiş (Kilis Günlük Halk Gazetesi, 16.08.1937, s. 1), Hataylı Türkler, Türkiye'ye iltica etmeye başlamıştır (Kilis Günlük Halk Gazetesi, 19.08.1937, s. 1). Hatay'da görevli delegenin istifası üzerine Hatay'a yeni gelen Fransız delegesi, Sancağın geleceğinin Milletler Cemiyeti Nezareti’ne bağı olduğunu söylemiş̧tir (Kilis Günlük Halk Gazetesi, 09.09.1937, s. 3). Kısa bir süre sonra askeri karakollar kaldırlmış ve karışıklık çıkaranların cezalandırlacaklarını bildiren bir beyanname yayınlanmıştır (Kilis Günlük Halk Gazetesi, 23.09.1937, s. 1).

Yaşanan olaylarla ilgili Avrupa basınında sik sık haberler yer almıştır. Paris Republique gazetesinde yayınlanan bir makalede Türkiye'nin İskenderun Sancağı ahalisine kendi Türkçe ismi ile "Hatay" ismini verdiği, buradan gelecek olan yolcu ve eşyadan pasaport ve gümrük vergisi istemediği, Hatay'in mülk sahiplerine kredi açacağ ile ilgili haberler yer almıştr. Makalede bütün bunların Ankara Hükümeti'nin Sancağı temsil etmeye hazırlandığı anlamına geldiği ifade edilmiştir (Kilis Günlük Halk Gazetesi, 23.08.1937, s. 2).

30 Ağustos 1937'de İskenderun ve Antakya'da resmen Türk konsolosluklarının açlması ile Türkiye Hatay'da daha etkin bir siyaset izlemeye başlamıştr. Beyrut Başkonsolosu Faik Zihni Bey tarafindan yürütülen konsolosluk görevine (Akçora, 2000, s. 343) Paris Konsolosu Firuz Bey atanmış (Kilis Günlük Halk Gazetesi, 30.08.1937, s. 2) ve başkonsolos unvanını almıştır (Kilis Günlük Halk Gazetesi, 13.09.1937, s. 1). Antakya Türk Başkonsolosluğu Kançılarlığına ise Orhan Güney atanmıştır (Kilis Günlük Halk Gazetesi, 23.09.1937, s. 1). Bütün bu gelişmelere rağmen sular durulmamışsır. Suriyeliler ve bazı Fransız milletvekilleri tarafindan Antakyaİskenderun ve havalisinin Suriye'nin ayrlmaz bir parçası olduğunu ispat etmek için yazilar, broşürler ve kitaplar yayınlanmıştrr. Hatay'da posta işleri ile ilgilenen Fransızlar, Hatay bölgesine Suriye dedikleri için (Kilis Günlük Halk Gazetesi, 22.11.1937, s. 2), Türkiye'nin çeşitli bölgelerinden Antakya'ya gönderilen mektupların üzerine Antakya Postanesi'nde "Suriye'de Hatay mıntıkası mevcut değildir" ibaresini yazarken (Kilis Günlük Halk Gazetesi, 06.09.1937, s. 1), gazetelerin üzerine ise "Adres kâfi değildir" diyerek geri iade etmişlerdir (Kilis Günlük Halk Gazetesi, 13.01.1938, s. 1).

\section{Hatay'da Seçimlerin Ertelenmesi}

Hatay anayasasının 29 Kasım 1937 yllında yürürlüğe girmesi kabul edilmiş̧i. Fakat öncelikle 
seçimlerin yapılması gerekiyordu. Bu nedenle Hatay'daki seçimleri kontrol etmek üzere Milletler Cemiyeti tarafindan beş kişilik bir heyet seçilmiştir (Kilis Günlük Halk Gazetesi, 11.10.1937, s. 1). Bu heyet, Cenevre'den Hatay'a gelerek görevine başlamıştır (Kilis Günlük Halk Gazetesi, 14.10.1937, s. 3). Heyetin görevi, Hatay seçimini Milletler Cemiyeti’nin verdiği talimata göre kontrol etmek ve seçim nedeni ile Hatay ve çevresini karıştıranları engellemek olmuştur (Kilis Günlük Halk Gazetesi, 04.11. 1937, s. 1). Fakat seçim sistemi meselesinde Türkiye ile Fransa arasında görüş ayrılığı çıkmıştır (Armaoğlu, Tarihsiz, s. 350). Statüdeki yeni rejim hükümlerine rağmen Hatay'da Türkçe’nin hala resmi dil olarak kullanılmaması ve Hatay maliyesine Türklerin tayin edilmemesi iki ülke arasındaki görüş ayrılığının derinleşmesine neden olmuştur (Kilis Günlük Halk Gazetesi, 10.01.1938, s. 1). Bütün bunlara ilaveten Milletler Cemiyeti'nin Hatay seçimlerine hazırlık için gönderdiği heyet, hazırlanacak olan seçim yönetmeliğinde bazı hatalar yapmıştır (Kilis Günlük Halk Gazetesi, 31.01.1938, s. 2). Heyet, Cenevre'ye dönerek konseye hazırlamış oldukları raporu sunmuştur (Kilis Günlük Halk Gazetesi, 20.12.1937, s. 1).

Fransız La Republique Paris gazetesinin 4 Aralı 1937 tarihli sayısında Hatay Meselesi hakkında Suriye Anlaşması'nın Türkiye ile Fransa'nın arasını bozma ihtimali gösterdiğine dair bir yazı yayınlanmıştır. Yazıda 1535'den beri Fransa'nın Türkiye'nin dostu olduğu fakat Fransa-Suriye anlaşması ile Sancak meselesinin ortaya çıktığı ve bu nedenle Paris ile Ankara arasındaki münasebetlerin gerginleştiği ifade edilmiştir (BCA, 222501-22, 12.12.1937, 30.10.0-0/Muamelat Genel Müdürlüğü). Türkiye 3 ve 24 Aralık 1937 tarihlerinde Fransa’ya verdiği notalarla durumu protesto etmiş ve 1930 tarihli Türk Fransız Dostluk Anlaşmasını feshettiğini bildirmiştir (Sarınay, 2000, s. 378). Fransız Le Tempa Paris gazetesinin 29 Aralık 1937 tarihli sayısında Sancak'taki seçimden bahsedilmiştir. Haberde Ankara Hükümeti'nin raporun kendisine danışılmadan hazırlandığını, statü ibarelerinin taraflı bir şekilde yorumlandığı ve bu nedenle kabul edilen kararların kıymetinden şüphe ettiğine dair haberler yer almıştır. Bunun üzerine konsey Türk çekincelerinin tetkik edilmesine karar vermiştir (BCA, 223-502-5, 05.01.1938, 30.10.0-0/Muamelat Genel Müdürlüğ̈̈).

\section{Türkiye-Suriye İyi KomşulukAnlaşması’nın Feshinin Yabancı Basına Yansıması}

Fransa ile yaşanan gerginlik üzerine Türkiye, Suriye ile 1926'da imzaladığı İyi Komşuluk Anlaşmasını feshetmiştir. Anlaşmanın bazı hükümlerinin uygulanamadığı, bazı hükümlerinin yorumlanmasında ise her iki taraf arasında anlaşmazlıklar çıktığı ifade edilmiştir. Anlaşmazlığa neden olan olaylardan biri de sınırın güneyinde kalan 520 köydeki emlakin durumu olmuştur. Bu nedenle Türk yetkililer anlaşmanın günün şartlarına uygun bir şekilde yeniden düzenlenmesi gerektiğini Fransa Hükümeti’ne bildirmiştir (Kilis Günlük Halk Gazetesi, 13.12.1937, s. 1). Fransız La Depeche de Toulouse gazetesinin 8 Aralık 1937 tarihli baskısında Türkiye tarafindan anlaşmasının feshinin, Suriye Hükümeti'nin, Sancağın yeni statüsünün tatbikinde gösterdiği zorluktan kaynaklandığı ifade edilmiştir. Ayrıca Türkiye'nin bu anlaşmayı yeni şartlara intibak ettirmek için müzakerelerin açılmasını arzu ettiği, Suriye'de Fransız mandası devam ettiği için görüşmelerin Türk, Fransız ve Suriye hükümetleri arasında cereyan etmesinin muhtemel olduğu yazılmıştır. Fransız La Republique gazetesinin 8 Aralık 1937 tarihli sayısında ise Suriye parlamentosunun Sancak statüsünü reddettiğine dair haberler yer almıştır (BCA, 


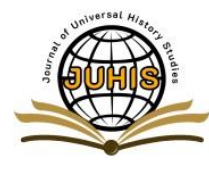

222-501-24, 16.12.1937, 30.10.0.0/Muamelat Genel Müdürlüğü/Dosya Ek: 402; Özüçetin, Kaya, 2018, s. 8). Fransiz L'ere Nouvelle Paris gazetesinin 16 Aralık 1937 tarihli sayısinda Ankara Hükümeti’nin yeni bir anlaşmanın yapılması için görüş̧me talebinde bulunduğu iddia edilmiştir (BCA, 222-501-27, 24.12.1937, 30.10.0.0/Muamelat Genel Müdürlüğü/Dosya Ek: 402).

\section{Hatay Meselesinin Çözümü}

1938 ylı başından itibaren Avrupa'da uluslararası ilişkiler giderek gerginleşmeye başlamıştr. BerlinRoma mihverinin Avrupa'da ağıllı̆ııı giderek arttırması, Fransa ile Türkiye arasındaki ilişkilerin düzelmesine neden olmuştur. Fransa'da yayın yapan Figaro gazetesindeki bir makalede Türk siyasetinin çok yönlü olduğu, bu nedenle Türkiye'nin diğer devletlerle ittifak yapabileceğinden bahsedilmiş̧tir (BCA, 222-501-24, 16.12.1937, 30.10.0.0/Muamelat Genel Müdürlüğü/Dosya Ek: 402; Özüçetin, Kaya, 2018, s. 7). 30 Ocak 1938'de Paris'te yapılan görüşmeler, Avrupa'daki gelişmelerin oluşturduğu hava içinde geçmiş, Türk yetkililer yeni bir TürkFransız anlaşması yapabileceklerini ima etmişlerdir. Milletler Cemiyeti ise Türkiye'nin itirazını dikkate almış (Kara, 2017, s. 126) ve 31 Ocak günü İsveç temsilciliğinin başkanlğında oluşturulacak bir komiteyle yönetmelikte gerekli düzeltmelerin yapılmasına karar vermiş̧ir (Akçora, 2000, s. 344). Hatay seçimi hakkında Cenevre'de Türk ve Fransız yetkilileri arasındaki görüşmelere İngiliz Hariciye Nazırı da iştirak etmiş, prensipte anlaşmaya varılmıştır (Kilis Günlük Halk Gazetesi, 31.01.1938, s.1). Türk Hükümeti’nin yapttğı protesto Fransa ve İngiltere Hariciye nazırları ile Milletler Cemiyeti Konseyi tarafindan haklı görülerek bunun düzeltilmesi için komisyonun çalışması, buna imkân hazırlamak için de seçimin bir müddet ertelenmesi kararlaştırımıştır (Kilis Günlük Halk Gazetesi, 03.02.1938, s. 1). Fakat gerginlik devam etmiştir. Hatay'da nüfus işleri için ayn hâkimlikler kurulmasına rağmen (Kilis Günlük Halk Gazetesi, 20.12.1937, s. 1) nüfus işleri ile ilgili olarak Türklerin kayıtlarında sorun çıkmıştr (Kilis Günlük Halk Gazetesi, 24.01.1938, s. 4). Fransızlar tarafindan kurulan yeni Adliye Teşkilatı çalışmaya başlamış, yeni kurulan mahkemelerin reisliğine Fransızlar, azalıklara da Türk olmayanlar tayin edilmiştir. Nüfus hâkimi azledilmiş, yenisi de görevine gelmediği için halkın nüfus işleri aksamıştır (Kilis Günlük Halk Gazetesi, 27.12.1937, s. 2). Bir süre sonra Antakya'nın Karamurt nahiyesi Türk nüfusa ait sicil defteri çalınmıştır (Kilis Günlük Halk Gazetesi, 30.12.1937, s. 1).

Hatay seçim nizamnamesini yeniden düzenlemek amacı ile Hariciye Vekâleti Umumi Kâtibi refakatindeki heyet Cenevre'ye gitmiştir (Kilis Günlük Halk Gazetesi, 07.03.1938, s. 2). Seçim nizamnamesindeki gerekli düzeltmeler 7 Mart 1938'de yapılmıştır. 12 Mart 1938 günü delegeler tarafindan bir karar yayınlanmış ve 29 Kasım 1938 günü Sancak Bağımsızlık Günü olarak resmi bayram ilan edilmiştir (Akçora, 2000, s. 344). Hatay seçim nizamnamesini hazırlamak için Cenevre'ye giden heyet yurda döndükten sonra Türkiye-Suriye İyi Komşuluk Anlaşması'nın imzalanması için yapılacak müzakerelerin hazırlığına başlanılmıştr (Kilis Günlük Halk Gazetesi, 28.03.1938, s. 2).

Farklı ülkelerde yaşayan Hataylılar yapılacak seçimlerde oylarıı kullanmak için Hatay’a gelmiştir. (Kilis Günlük Halk Gazetesi, 10.01.1938, s. 1). Oy kullanmak için gelen Abdurrahman Melek, İskenderun Sancağı valisi olmuștur. 15 Nisan 1938'de Hatay'da yeniden bir takım karşskllk meydana gelmiş̧ir (Akçora, 
2000, s. 343-344). Reyhaniye'de bir sabıkalı, kavga ettiği kişinin üzerine tüfeği ile ateş etmiş, çıkan kurşunlar bir Türk kızına isabet ederek ağır yaralanmasına sebep olmuştur (Kilis Günlük Halk Gazetesi, 4.03. 1938, s. 1). Türkmen köyler yağmalamış (Kilis Günlük Halk Gazetesi, 14.04.1938, s. 3), şapka giydiğinden dolayı hakkında takibat yapılan 70 yaşındaki bir kişi darp edilmiştir (Kilis Günlük Halk Gazetesi, 21.03.1938, s. 1). Cenevre'de kabul edilen "partilerin lağvı ve particilerin silahtan tecridi” hakkındaki karar uygulanmamıştır (Kilis Günlük Halk Gazetesi, 18.04.1938, s. 1). İskenderun'un Mahmutlu Türk köyündeki milli emlakin Ermenilere dağıtılacağı vaat edilmiştir (Kilis Günlük Halk Gazetesi, 31.03.1938, s. 1). Bu gelişmeler yaşanırken çoğunluğu Türk olan Bayır, Bucak nahiyeleri ile Cerablus halkı anavatana ilhak edilmelerini talep etmiştir. Cerablus Türklerinin Bomboş, Bab ve Azaz kazalarına taksim edilmesi, bölge halkının şikâyet ve protestolarına neden olmuştur (Kilis Günlük Halk Gazetesi, 11.04.1938, s. 1).

Milletler Cemiyeti’nden oluşan heyet, gördüğü lüzum üzerine seçimi 5-10 gün ertelemiştir. 36 farklı alana sandıklar konmuş, her sandık iki kişi tarafindan korunmuştur (Kilis Günlük Halk Gazetesi, 02.05.1938, s. 1). Hatay'da Nisan 1938'de yapılması gereken seçimler 3 Mayıs 1938'de Milletler Cemiyeti Seçim Komisyonu'nun gözetimi altında başlamıştır (Kara, 2017, s. 126). Fakat karışıklıklar devam etmiştir. Aktepe'de kayıt işlemleri esnasında Mehmet Haco isimli şahıs, bir Türk’e saldırmış, bir süre sonra kendilerine katılan 35 silahlı kişi ile seçime gelenlere ve Aktepe Halkevine ateş etmeye başlamıștır (Kilis Günlük Halk Gazetesi, 16.05.1938, s. 1). Diğer taraftan Atatürk'ün ağır hasta olduğuna dair Beyrut kaynaklı telgraf ve radyo haberleri yayılmıştır (Kilis Günlük Halk Gazetesi, 26.05.1938, s. 1).

Türkiye birtakım önlemler almak için, Fransa ile görüşmeler yapmış, görüşmeler bir sonuç vermeyince Milletler Cemiyeti'nden çekilmiştir. Bunun üzerine Atatürk hasta yatağından kalkmış ve "Hatay’ı kurtaracağı" diyerek yola çıkmıştır (Kutay, 1988, s. 57). Atatürk'ün 19 Mayıs 1938'de Gençlik ve Spor Bayramı'nı izledikten sonra (Leventoğlu 1968, s. 27) Mersin'e gitmesi, Fransa’nın Hatay üzerindeki tutumunda köklü değişiklikler yapmasına neden olmuştur (Akçora, 2000, s. 345). Fransa'nın seçim dönemi oyalama taktiklerinden dolayı tepkili olan Mustafa Kemal, Hatay'a girecek birliklerin hazır edilmesini istemiş̧ir (Kara, 2017, s. 127). Mecliste ise Hatay meselesine temas edilerek Fransa'nın tutumu eleştirilmiştir (Kilis Günlük Halk Gazetesi, 02.06.1938, s. 1). Başbakan Celal Bayar, Hatay meselesinin tarihçesi ve son kritik devreleri hakkında bilgiler vermiştir (Kilis Günlük Halk Gazetesi, 13.06.1938, s. 1).

5 Haziran 1938'de Sancak Umum Valisi Abdurrahman Melek göreve başlamıştır. Bir gün sonra Fransız delege görevden çekilmiş, yerine Yarbay Colet getirilmiştir. Yarbay Colet ilk icraat olarak sikıyönetim ilan etmiştir. Abdurrahman Melek ise ilk icraat olarak Süreyya Halef’i Antakya kaymakamlığına, Vedi Münir Karabay'ı da Antakya Belediye Reisliğine tayin etmiştir. Fransa ile Türkiye arasında Hatay konusunda bir anlaşma sağlanmış ve uygulama esaslarının belirlenmesi için Genelkurmay İkinci Başkanı Orgeneral Asım Gündüz İskenderun'a gelmiştir (Akçora, 2000, s. 345). Bu arada Hükümet dairelerine de yüzde yetmiş beş oranında Türk unsuru yerleştirilmiştir (Kilis Günlük Halk Gazetesi, 13.06.1938, s. 1). 
Hatay'da mülki ve askeri idareyi eline almış olan Colet, asayişi bozanlanı cezalandıracağını ve halkın huzur içinde oy kullanma işlemini gerçekleştireceğini söylemiştir (Kilis Günlük Halk Gazetesi, 13.06.1938, s. 1). Çok geçmeden bütün kayıt büroları tekrar faaliyete başlamış, Yarbay Colet ile Vali Abdurrahman Melek nahiyeleri dolaşarak alınan tedbirleri kontrol etmiştir (Kilis Günlük Halk Gazetesi, 16.06.1938, s. 1).

Fransa Şark Orduları Kumandanı Orgeneral Hutsinjer başkanlığı altındaki Fransız askeri heyet ile Genelkurmay İkinci Başkanı Orgeneral Asım Gündüz’ün başkanlığındaki Türk heyet arasında İskenderun ve Antakya'da bir görüşme gerçekleşmiştir (Kilis Günlük Halk Gazetesi, 16.06.1938, s. 1). Yugoslavya'da yayın yapan Vreme-Belgrat gazetesinin 30 Haziran 1938 tarihli sayısında Türkiye ile Fransa arasında bütün noktalarda mutabakat sağlandığına dair haberler yer almıştır (BCA, 224-509-28, 30.06.1938, 30.10.0.0/Muamelat Genel Müdürlüğü/Dosya Ek: 402). Antakya'da askeri heyetleri arasında yapılan görüşmeler sonucunda, 3 Temmuz 1938'de Türk-Fransız Askeri Anlaşması imzalanmıştır (Eroğlu, 1986, s. 132). Anlaşmaya göre Hatay’ın toprak bütünlügü güvence altına alınmış ve halkın arzusunu tayin edecek bir halkoyu araştırması yapılıncaya kadar bu bölgenin işleri ile uğraşmak üzere Fransız ve Türk askeri kuvvetleri arasında bir işbirliği düzeni kurulmuştur (Villalta, 1982, s. 694). Çok geçmeden Milletler Cemiyeti Umumi Kâtipliği, Hatay’a gönderilen komisyonun çalışmalarına son vermesi gerektiğini komisyona iletmiştir. Bunun üzerine Hatay'daki komisyon bir hafta içinde Hatay'ı terk edeceklerini Milletler Cemiyeti Umumi Kâtipliğine telgrafla bildirmiştir (Kilis Günlük Halk Gazetesi, 30.06.1938, s. 1). Anlaşma gereği Hatay’ın toprak bütünlüğü ile siyasi statüsünü korumak amacı ile her iki devlet 2500'er kişilik askeri kuvvet göndermeyi kabul etmiştir (Eroğlu, 1986, s. 132). Lazkiye'de 2000 mevcutlu bir Senegalli kıtaya ilaveten bir Türk kıtası da Payas'tan Hatay’a hareket etmiştir (Kilis Günlük Halk Gazetesi, 23.06.1938, s. 1). Hatay baştanbaşa süslenmiş Türk askerinin gelmesi beklenmiştir (Kilis Günlük Halk Gazetesi, 30.06.1938, s. 1). Albay Şükrü Kanatlı komutasındaki Türk askeri, 5 Temmuz günü Payas ve Hassa üzerinden Hatay'a girmiştir (Karakoç, 2009, s. 109). Tugayın Hatay’a girmesi, Meclis seçimlerinin güven içinde yapılacağı yönündeki inancın kuvvetlenmesine neden olmuştur (Akçora, 2000, s. 347).

Paris’te başlayan ve sonradan Ankara'da devam eden Türk Fransı görüşmeleri de 4 Temmuz'da Ankara'da Türk Dışişleri Bakanı ve Fransa'nın Ankara büyükelçisi arasında yapılan bir dostluk anlaşması ile sonuçlanmıştır (Gönlübol ve Sar, 1997, s. 138). Bu antlaşma ile 29 Mayıs 1937 tarihinde kabul edilen İskenderun Sancağ Statüsü ve Anayasasının yürürlüğe girmesi, Fransa tarafindan kabul edilmiş ancak meselenin Türkiye için toprak sorunu olmadığı teyit edilmiştir. Anlaşma, Türkiye’nin feshettiği 1930 tarihli Dostluk Antlaşması'nın yerine geçmek üzere planlanmıştır (Atabey, 2015, s. 198). Neue Zürcher Zeitung gazetesinin 24 Haziran 1938 tarihli sayısında Fransa'nın, İskenderun Limanı'na eskisi kadar önem vermediğine dair haberler yer almışır (BCA, 224-509-28, 30.06.1938, 30.10.0.0/Muamelat Genel Müdürlüğü/Dosya Ek: 402). Bu gelişmeler yaşanırken Yugoslavya'da yayınlanan yarı resmi Novosti-Zagrep gazetesinin 29 Haziran 1938 tarihli nüshasında anlaşmaya yönelik tepkilere yer verilmiştir. Suudi Arabistan'ın bazı yerlerinden Milletler Cemiyeti’ne ve Fransa Hükümeti'ne protesto telgrafları gönderilmiş, Arap çevresinin Sancak meselesinin çözümlenme şeklinin Milletler Cemiyeti'nin bir başarısızlığı olarak telakki ettiği bildirilmiştir (BCA, 402, 224-509-28, 30.06.1938, 30.10.0.0/Muamelat Genel Müdürlüğü/Dosya Ek:). 
Türk ve Fransız Hükümetleri, statü ve anayasanın tatbikini temin etmek için Sancak’ta ilk seçim işlerinin kontrolünü birlikte yapmaya karar vermiştir. İki devletin temsilcileri, seçim işlerinin kesinlikle ihlaline izin vermeyeceklerini ve gerekli tedbirleri alacaklarını taahhüt etmişlerdir (Karakoç, 2009, s. 109). Seçimle ilgili olarak kayıt işleri devam etmiştir (Kilis Günlük Halk Gazetesi, 01.07.1938, s. 1). Kısa bir süre sonra Fransızların Hatay'daki temsilcisine seçimleri düzenleme yetkisi verilmiştir (BCA, 224-511-6, 13.07.1938, 30.10.00/Muamelat Genel Müdürlüğü). Hatay’da yapılacak seçimlerde Türkiye adına seçim işlerini düzenlemekle Cevat Açıkalın görevlendirilmiştir. Cevat Açıkalın 14 Temmuz günü Antakya’ya hareket ederek Yarbay Colet ile kısa bir görüşme yapmıştır. İkili arasında yapılan görüşmede seçim işleri konusunda bir mutabakat sağlanmıştır. (BCA, 224-511-9, 16.07.1938, 30.10.0.0/Muamelat Genel Müdürlüğü, Dosya Ek: 402). Türk-Frans1z yakınlaşması sonucu 22-31 Temmuz 1938 tarihleri arasında Hatay seçimlerinin ortaklaşa yönetilmesi için bir yüksek seçim kurulu oluşturulmuştur (Kilis Günlük Halk Gazetesi, 18.08.1938, s. 2). Bütün cemaatler seçim komisyonunca belirlenen miktarda aday göstermiş (Kilis Günlük Halk Gazetesi, 25.08.1938, s. 1) ve 13 Ağustos'ta seçimler yapılmıştır. Meclis çoğunluğunu Türkler kazanmış ve Bağımsız Hatay Cumhuriyeti 12 Eylül 1938'de kurulmuştur (Kara, 2017, s. 125). Antakya Başkonsolosu Celal Karasapan, başka bir yere nakil istemiştir (BCA, 224-511-6, 13.07.1938, 30.10.0-0/Muamelat Genel Müdürlüğ̈̈). Bunun üzerine İskenderun konsolosu Fethi Denli, Antakya konsolosluğuna tayin edilmiştir (Kilis Günlük Halk Gazetesi, 22.08.1938, s. 1).

Hatay Meclisi’nin 2 Eylül 1938 Cuma günü açılması kararlaştırlmıştır. Kabine, Meclisin açılmasından ve devlet reisinin seçilmesinden sonra teşekkül etmiştir. Meclisin açılacağı tarih olan 2 Eylül gününün Hatay'da milli bayram sayılmasına ve her sene kutlanmasına karar verilmiştir (Kilis Günlük Halk Gazetesi, 29.08.1938, s. 1). Tayfur Sökmen Hatay’a gelmiş (Kilis Günlük Halk Gazetesi, 01.09.1938, s. 2), Hatay Millet Meclisi’nin en yaşı mebus tarafindan açılmasına ve hemen ardından devlet reisi seçilmesine karar verilmiştir. Yapılan görüşmelerden sonra merasim programı tespit edilmiştir. Programda kanun karşısında hiç kimseye imtiyaz tanınmayacağı, bütün Hataylıların şerefi, haysiyeti, ırzı, malı, kazancı ve ibadetinin eşit bir şekilde korunacağı belirtilmiştir (Kilis Günlük Halk Gazetesi, 05.09.1938, s. 1).

\section{Hatay'm Anavatana Katılması}

Hatay Meclisi, en yaşı aza olan Mehmet Adalı'nın bir konuşması ile açılmış ve Meclis reisliğine Abdülgani Türkmen seçilmiştir. Mustafa Kemal Atatürk, Türkiye Hükümeti’nin Hatay meselesindeki başarısını ve Hatay Meclisi'nin açıldığını Hariciye Vekâletinden haber alır almaz bir kutlama telgrafi çekmiştir (Kilis Günlük Halk Gazetesi, 08.09.1938, s. 1). Tayfur Sökmen 2 Eylül 1938'de Hatay'ın ilk Cumhurbaşkanı seçilmiş, Başbakanlığa ise Abdurrahman Melek atanmıştır (Akçora, 2000, s. 348). Meclis, 2 Eylül 1938'de ilk toplantısını yapmıştır (Eroğlu, 1986, s. 132). Aynı gün Türk Hükümeti, Cevat Açıkalın'ı Hatay olağanüstü temsilcisi olarak atamıştır. 6 Eylül 1938'de Hatay'ın ilk kabinesi mecliste hükümet programını okuduktan sonra güvenoyu almış, anayasa kabul edilmiştir. Anayasanın birinci maddesinde Sancak kelimesi yerine "Hatay Devleti" ibaresi yer almıştır. Yönetim şekli ise cumhuriyet olarak birinci maddede belirtilmiştir. Aynı gün al zeminin üzerinde beyaz ay ve ortasında al bir yıldızın olduğu bayrak, Hatay Bayrağı olarak kabul edilmiştir. İstiklal Marşı ise Hatay 
Devleti’nin Milli Marşı olarak kabul edilmiştir (Karakoç, 2009, s. 109).

Hükümet kurulduktan sonra, birçok alanda yenilikler yapmıştır. Hatay'ın imarı ve kalkınması için çalışılmıştır (Kilis Günlük Halk Gazetesi, 22.09.1938, s. 1). Hatay reji idaresi, Suriye rejisi ile olan bağını keserek müstakil olarak idare edilmeye başlanmıştır (Kilis Günlük Halk Gazetesi, 16.01.1939, s. 3). Hatay'da Atlı Spor Kulübü kurulmuş, İskenderun'da yurt açılmış, Merkez Bankası'nın Hatay'da bir şube açmasına izin verilmiştir (Kilis Günlük Halk Gazetesi, 09.3.1939, s. 1).

Yeni hükümeti bekleyen büyük zorluklardan biri de Hatay hudut kapısının Türkiye’ye kapalı olması ve Suriye-Hatay kapısının da Fransızlar tarafindan kapatılması sorunu olmuştur. Suriye-Hatay hududunun tespiti için Ankara'da Fransa Hariciye Nazını ile görüşmeler yapılmıştır (Kilis Günlük Halk Gazetesi, 12.09.1938, s. 1). Konu ile ilgili olarak Türk-Fransız Heyeti Hamam köyü arazisini incelerken anlaşmazlığa düşmüştür (Kilis Günlük Halk Gazetesi, 28 Kasım 1938). Fransızların sınır kapısını kapatması üzerine Türkiye, sınırını Hatay’a açmıştır (Akçora, 2000, s. 349). Zorluklar bununla da kalmamıştır. Suriye, Hatay’a un ihracını yasaklamış, bu nedenle Ziraat Bankası tarafindan Hatay'a 300 ton buğday gönderilmiştir (Kilis Günlük Halk Gazetesi, 07.11.1938, s. 1). Kısa bir süre sonra Türkiye ile Hatay arasındaki yakınlık ve bağgllığın faydalı bir şekilde gelişmesini temin edecek esaslar yürürlüğe konmuştur (BCA, 86-15-10, 24.02.1939, 30.18.1-2/Kararlar Daire Başkanlığı, Dosya Ek: 402). Hatay Devleti, Türkiye Cumhuriyeti kanunlarını kabul etmiş (Uçarol 2000, s. 593) buna karşlık Türkiye ise Hatay menşeli mamullerde gümrüklerde indirim yapmıştır (Kilis Günlük Halk Gazetesi, 21.11.1938, s. 1). 1 Aralık 1938'de Hatay Türklerinin Türkiye’ye gümrüksüz girmesi hakkında kanun yürürlüğe girmiş, Hatay Hükümeti de Türkiye'den gelenlerin sadece nüfus kâğıdı ile Hatay’a girmelerini kabul etmiş̦ir (Karakoç, 2009, s. 110). Cumhuriyet Bayramını büyük bir heyecan ile kutlayan Hatay halkı, Türkiye'ye bir heyet göndermiştir (Kilis Günlük Halk Gazetesi, 07.11.1938, s. 1). Hatay’ın uluslararası posta haberleşmesinin Suriye pullarıyla yapılmasını önlemek için gerekli tedbirler alınmışıఁ (BCA, 85-110-4, 02.01.1939, 30.18.1-2/Kararlar Daire Başkanlığı, 1928-). Hatay Millet Meclisi 30 Ocak’ta Abdulgani Türkmen'in başkanlığında toplanarak Türk Ceza Kanunu'nun aynısı olan Hatay Ceza Kanunu'nu kabul etmiştir (Kilis Günlük Halk Gazetesi, 06.02.1939, s. 2). Hatay milletvekillerinin Türkiye Cumhuriyeti Devlet Demiryollan'nda parasız seyahat edebilmeleri hakkında kanun kabul edilirken Anayurttan Hatay'a gelecek vatandaşlara da her türlü kolaylığın gösterilmesi istenmiştir (Kilis Günlük Halk Gazetesi, 16.02.1939, s. 2). İskenderun'da serbest Türk limanı kurulmasına karar verilmiş (Kilis Günlük Halk Gazetesi, 09.02.1939, s. 1), İskenderun Limanı'nda kurulacak olan Türk mıntıkası hakkındaki incelemeyi yapmak üzere Türk gümrük görevlileri Hatay’a gitmiştir (Kilis Günlük Halk Gazetesi, 20.02.1939, s. 2). Ayrıca Payas-İskenderun hattının, devlet demiryollanı işletmesine teslimine (Kilis Günlük Halk Gazetesi, 10.07.1939, s. 1), Hatay'da Türk parasının kullanılmasına (Kilis Günlük Halk Gazetesi, 27.02.1939, s. 1) ve memurların aylıklarının Türk Lirası olarak ödenmesine karar verilmiştir (Kilis Günlük Halk Gazetesi, 06.03.1939, s. 2).

Hatay meselesinin çözz̈mü dış basında geniş bir şekilde yer almıştır. İngiltere'de çıkan The Truth dergisinde Hatay meselesi ile ilgili olarak Türkiye'nin başarısından bahsedilmiştir. İlaveten nüfusunun büyük çoğunluğu Türk olan Hatay'da sorunun çözümünün Türk diplomasisinin bir zaferi olduğu, yeni doğan devletin 
Türkiye'nin nüfuzu altında olacağını kabul ettiğinin anayasadan ve hatta isminden belli olduğu ifade edilmiştir (Kilis Günlük Halk Gazetesi, 10.10.1938, s. 1).

1939 yılının Mart ayında Türkiye'de yapılacak milletvekili seçiminde Tayfur Sökmen'in Antalya'dan, Abdurrahman Melek'in Gaziantep'ten aday gösterilmeleri ve Büyük Millet Meclisi'ne seçilmeleri Hatay'ın anavatana ilhak edilmek üzere bulunduğu kanaatini ortaya çıkarmıştır (Akçora, 2000, s. 350). Londra radyosu 23 Nisan gecesi yaptığı yayınında Hatay'ın Türkiye'ye iadesi hakkında Türkiye ile Fransa arasında tam bir anlaşma sağlandığını ve çok yakında Hatay'ın Türkiye'ye iadesi için devir, teslim işine başlanacağını iddia etmiştir (Kilis Günlük Halk Gazetesi, 27.04.1939, s. 1). Bu sıralarda Avrupa'da genel bir savaşın çıkacağı artık belli olmuştur. Durumdan endişe duyan Fransa ve İngiltere Ortadoğu ve Balkanlardaki çıkarları gereği Türkiye'ye yaklaşma ihtiyacı hissetmiştir. Bunun üzerine Türkiye ve Fransa arasında 23 Haziran 1939'da “Türkiye ile Suriye Arasında Toprak Sorununun Kesinlikle Çözümüne İlişkin Anlaşma” imzalanmıştır (Uçarol, 2000, s. 593). Anlaşma Ankara'da Hariciye Vekili Şükrü Saraçoğlu ile Fransa Büyükelçisi Masigli, Paris’te Fransa Hariciye Nazırı Bonne ile Büyükelçi Suat Davaz'ın katılımıyla imzalanmıştır (Kilis Günlük Halk Gazetesi, 26.06.1939, s. 1). Türkiye ile Suriye arasındaki toprak sorunu kesin olarak çözülerek iki ülke sınırı belirlenmiştir. Fransa Hatay’ın Türkiye'ye katılmasına razı olmuş, Hatay'da bulunan Fransız kuvvetlerinin bir ay içinde ülkeyi boşaltmasını kabul etmiştir. Hatay Meclisi de 29 Haziran'da oy birliği ile Türkiye'ye katılma kararın almıştır (Karakoç, 2009, s. 110). Hatay vilayetinin merkezi Antakya şehri olmuştur. Hatay'ın Türkiye'ye iadesi münasebeti ile Fransız basını ve birçok Avrupa gazetesi, Fransa'nın bir karış yer vermek istemediği halde önemli bir toprak parçasını terk etmekle Türkiye'ye karşı sempati göstermiş olduğundan bahsetmiştir (Kilis Günlük Halk Gazetesi, 26.06.1939, s. $1)$.

Hariciye Umumi Kâtibi Numan Rıfat Menemencioğlu Hatay'ın Türkiye arazisine ilhak edildiğini ve asıl büyük bayramın 23 Temmuz'da yapılacağını açıklamıştır. Çok geçmeden Payas’taki ilk sınır taşı törenle sökülerek Antakya'ya götürülmüsstür (Kilis Günlük Halk Gazetesi, 29.06.1939, s. 1). Hatay vilayeti kurulmasına dair olan 3711 numaralı ve 7 Temmuz 1939 tarihli kanunun geçici beşinci maddesinin değiştirilmesi hakkında kanun kabul edilmiş ve Hatay anavatana ilhak edilmiştir (BCA, 88-92-7, 13.09.1937, 30.18.1-2/Kararlar Daire Başkanlığı 1928). 23 Temmuz 1939 günü Hatay’a gelen Türk heyetinin de katılımı ile üç gün süren bir tören yapılmıştır (Akçora, 2000, s. 351). İslahiye kazasına bağlı Hassa nahiyesi Hatay'da teşkil edilen yeni vilayete bağlanmıştır (Kilis Günlük Halk Gazetesi, 31.07.1939, s. 4). Hatay 63. vilayet olarak Türkiye’ye katılmış, 'Kırk asırlık Türk yurdunun esir olamayacağını" haykıran ve onu kurtarmak uğrunda çok çalışan Atatürk'ün isteği yerine gelmiştir (Kilis Günlük Halk Gazetesi, 20.06.1939, s. 1).

\section{Sonuç}

Birinci Dünya Savaşı’ndan yenik çıkan Osmanlı Devleti’nin topraklanı İtilaf Devletleri tarafindan işgal edilmeye başlanmıştır. Henüz savaş devam ederken İngiltere ve Fransa kendi aralarında imzaladıkları Sykes Picot Anlaşmasıyla Anadolu'nun güney topraklarını aralarında paylaşmışlardır. Bağımsızlık mücadelesine giren Türk 


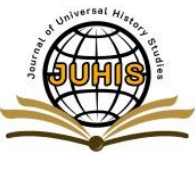

Milleti bütün cephelerde savaşmaya başlamıştır. Özellikle Batı Cephesinde kazanılan zaferler Türkiye'nin güçlenmesine neden olmuştur. Milli Mücadele sürerken kazanılan Sakarya Savaşı'yla İtilaf Devletleri arasındaki görüş ayrilı̆̆ derinleşmiş ve bunun sonucu olarak da Fransa ile 20 Ekim 1921 tarihinde Ankara Anlaşması imzalanmıştır. Ankara Anlaşması siyasi anlamda TBMM'nin ve Misak-1 Milli'nin İtilaf Devletleri tarafindan tanınmasını sağlamış olsa da bu anlaşma ile Hatay Fransa'ya bırakılmıştır. Çok geçmeden Fransa'nın 1936 yılında Suriye'deki manda yönetiminin kaldırarak, Suriye'ye bağımsızlığını vermesi ve Hatay'ın Suriye'de kalması, Fransa ile olan ilişkilerin gerginleşmesine neden olmuştur.

Meselenin çözümü için çok çalışan Mustafa Kemal Atatürk Milletler Cemiyeti’ne başvurmuş, hasta yatağından kalkarak bir yurt gezisine bile çıkmıştır. Atatürk’ün kararlı tavrı ve Avrupa'daki siyasi gelişmeler Fransa'nın Türkiye ile ilişkilerini geliştirmesine neden olmuştur. İngiltere, Almanya’nın yayılma siyasetini önlemek için Hatay sorununun çözümünde Türkiye ile Fransa'nın uzlaşması konusunda yoğun çaba sarf etmiştir. Hatay Devleti kurulduktan sonra yapılan düzenlemelerle manda yönetiminden kurtulmuş ve bağımsızlığını kazanmıştır. Bir yıla yakın varlığını sürdüren Hatay Devleti, 23 Haziran 1939 tarihinde hukuken ortadan kalkmış, Türkiye'nin bir vilayeti haline gelmiștir. Hatay'ın anavatana katılması, Mustafa Kemal Atatürk'ün ve Türk hükümetinin yoğun çalışması, kararlı duruşu ve izlenen politikaların başarılı olması sayesinde gerçekleşmiş ve kırk asırlık Türk yurdu düşman eline bırakılmamıştır.

Hatay meselesinin çözümünde Fransa ve Suriye ile olan ilişkiler, gerek yurt içinde gerekse yurt dışında basın yoluyla takip edilmiştir. Kilis küçük bir yerleşim yeri olmasına rağmen o tarihlerde yayın yapan Kilis Günlük Halk Gazetesi'nde Hatay sorunu ile ilgili birçok haber yer almıştır. Gazetede sorunun çözümü için bir taraftan Türk hükümetinin girişimleri ortaya konulurken, diğer taraftan Fransız ve Suriye Hükümeti'nin Hatay’1 ellerinde tutmak için izlediği politikalar ayrıntılı olarak ele alınmıştır. Gazetede yer alan haberler sayesinde Türk kamuoyu konu ile ilgili olarak bilgi sahibi olmuş ve sorunun çözümünde ortak duruş sergilenmiştir. 
Kilis Günlük Halk Gazetesindeki Haberlere Göre Hatay Meselesi/Nermin Zahide AYDIN

\section{Kaynakça}

[1] Akçora, E. (2000), Hatay'ın Anavatan'a İhakının Türk Dış Politikasındaki Yeri, Atatürk Dönemi Türk Dış Politikası, Semih Ofset, Ankara: s.327-353.

[2] Armaoğlu, F. (Tarihsiz), 20. Yüzyıl Siyasi Tarih. Alkım Yayınevi, İstanbul.

[3] Atabey, F. (2015), “Hatay'ın Anavatana Katılma Süreci”, Avrasya Uluslararast Araşttrmalar Dergisi, $4(7),(192-209)$.

[4] BCA, Yer: 222-501-24, Tarih: 16.12.1937-00.00.0000, Kurum:30.10.0.0/Muamelat Genel Müdürlüğ̈̈/Dosya Ek: 402.

[5] BCA, Yer: 222-501-27, Tarih: 24.12.1937-00.00.0000, Kurum:30.10.0.0/Muamelat Genel Müdürlüğü/Dosya Ek: 402.

[6] BCA, Yer: 223-502-5, Belge Tarih: 05.01.1938-00.00.0000, Kurum: 30.10.0-0/Muamelat Genel Müdürlüğü.

[7] BCA, Yer: 222-501-22, Tarih: 12.12.1937-00.00.0000, Kurum: 30.10.0-0/Muamelat Genel Müdürlüğü.

[8] BCA, Yer: 224-509-28, Tarih: 30.06.1938-00.00.0000, Kurum:30.10.0.0/Muamelat Genel Müdürlüğ̈̈/Dosya Ek: 402.

[9] BCA, Bilgisi: 224-511-6, Tarih: 13.07.1938-00.00.0000, Kurum: 30.10.0-0/Muamelat Genel Müdürlüğü.

[10]BCA, Yer: 88-92-7, Tarih: 13.09.1937-00.00.0000, Kurum: 30.18.1-2/Kararlar Daire Başkanlığı 1928.

[11]Bozkurt, İ. (2017), “Atatürk'ün Mersin Ziyaretleri”, Ankara Üniversitesi Türk Inkalap Tarihi Enstitüsü Atatürk Yolu Dergisi, (61), (79-110).

[12]Dağıstan A. ve Sofuoğlu, A. (2005), “Arşiv Belgeleri Işı̆̆ında Sancak (Hatay)'ın Bağımsızlık Sürecinin Illk Aşaması ve Türkiye”, Atatürk Araştırma Merkezi Dergisi, 21(61), (1-46).

[13]Dayı, E. (2001), “Hatay’ın Stratejik Önemi ve Türkiye-Suriye İlişkileri’, Misak-ı Milli'nin 80’inci Yıldönümünde İskenderun ve Çevresi Paneli, 5 Temmuz 2000, (31-42), Ankara. AKDTYK Atatürk Araştırma Merkezi.

[14]Doğramacı, E. (2001), 'Misak-1 Milli’nin 80'inci Yıldönümünde İskenderun ve Çevresi’, Misak-l Milli'nin 80'inci Yildönümünde İskenderun ve Çevresi Paneli, 5 Temmuz 2000, (9-16), AKDTYK Atatürk Araştırma Merkezi, Ankara.

[15]Eroğlu, H. (1986), Atatürk’ün Hayat, Kültür ve Turizm Bakanlığı Yayınları, Ankara.

[16]Gönlübol M. ve Sar C. (1997), Atatürk ve Türkiye’nin Dış Politikast (1919-1938), Atatürk Araşstırma Merkezi, Ankara. 
[17]İnan, A. (2013), Atatürk Hakkanda Hatralar ve Belgeler, Derleyen. An İnan, Türkiye İş Bankası Kültür Yayınlar, İstanbul.

[18]Kara, A. (2017), "Hatay'n Anavatana Katılmasi Hakkında Yeni Bir Belge”, U.U. International Journal of Social Inquiry, 10 (2), (117-134).

[19]Karakoç, E. (2009), “Atatürk’ün Hatay Davası”, Bilig, (50), (97-118).

[20]Kilis Günlük Halk Gazetesi, 6 Mayıs 1937, 10 Mayıs 1937, 13 Mayıs 1937, 19 Mayıs 1937, 24 Mayıs 1937, 31 Mayıs 1937, 3 Haziran 1937, 10 Haziran 1937, 14 Haziran 1937, 21 Haziran 1937, 24 Haziran 1937, 28 Haziran 1937, 1 Temmuz 1937, 5 Temmuz 1937, 8 Temmuz 1937, 12 Temmuz 1937, 15 Temmuz 1937, 19 Temmuz 1937, 22 Temmuz 1937, 29 Temmuz 1937, 12 Ağustos 1937, 16 Ağustos 1937, 19 Ağustos 1937, 23 Ağustos 1937, 30 Ağustos 1937, 6 Eylül 1937, 9 Eylül 1937, 13 Eylül 1937, 23 Eylül 1937, 11 Ekim 1937, 14 Ekim 1937, 4 Kasım 1937, 22 Kasim 1937, 13 Aralık 1937, 20 Arallk 1937, 27 Aralk 1937, 30 Aralık 1937, 10 Ocak 1938, 13 Ocak 1938, 24 Ocak 1938, 31 Ocak 1938, 3 Şubat 1938, 4 Mart 1938, 7 Mart 1938, 21 Mart 1938, 28 Mart 1938, 31 Mart 1938, 11 Nisan 1938, 14 Nisan 1938, 18 Nisan 1938, 2 Mayıs 1938, 16 Mayıs 1938, 26 Mayıs 1938, 2 Haziran 1938, 13 Haziran 1938, 16 Haziran 1938, 23 Haziran 1938, 30 Haziran 1938, 1 Temmuz 1938, 18 Ağustos 1938, 22 Ağustos 1938, 25 Ağustos 1938, 29 Ağustos 1938, 1 Eylül 1938, 5 Eylül 1938, 8 Eylül 1938, 12 Eylül 1938, 22 Eylül 1938, 10 Ekim 1938, 7 Kasım 1938, 21 Kasim 1938, 28 Kasım 1938, 16 Ocak 1939, 9 Şubat 1939, 16 Şubat 1939, 20 Şubat 1939, 27 Şubat 1939, 6 Mart 1939, 9 Mart 1939, 27 Nisan 1939, 20 Haziran 1939, 26 Haziran 1939, 29 Haziran 1939, 10 Temmuz 1939, 31 Temmuz 1939.

[21]Kutay, C. (1988), Ardinda Kalanlar, Cem Ofset, İstanbul.

[22]Leventoğlu, M. (1968), Atatürk'ün Vasiyeti, Bahar Matbaası, İstanbul.

[23]Melek, A. (1986), Hatay Nasll Kurtuldu, Türk Tarih Kurumu Basımevi, Ankara.

[24]Mursaloğlu, M. (2001), “İskenderun'un Stratejik Önemi ve Misak-1 Milli”, Misak-ı Milli'nin 80'inci Ylldönümünde İskenderun ve Çevresi Paneli, 5 Temmuz 2000, (77-85), AKDTYK Atatürk Araşturma Merkezi, Ankara.

[25]Özüçetin, Y. ve Kaya H. (2018), "Sancak (Hatay Meselesi) ve Bu Bağlamda Muhtelif Dış Basında Ortaya Konulan Yaklaşımlar ve Görüşler”, Asos Journal Akademik Sosyal Araşttrmalar Dergisi, (75), (1-15).

[26]Sarnnay, Y. (2000), Atatürk'ün Hatay Politikası I, Atatürk Dönemi Türk Dış Politikası, Semih Ofset, Ankara, (355-379).

[27]TBMMZC, D.1, C.1, İçima Senesi.1, İkinci Içctima, 24.4.1336.

[28]Tekin, M. (2009), Atatürk'ün Vazgeçilmez Davast Hatay, Colour Ofset, İskenderun.

[29]Uçarol, R. (2000), Siyasi Tarih (1789-1999), Filiz Kitabevi, İstanbul. 
Kilis Günlük Halk Gazetesindeki Haberlere Göre Hatay Meselesi/Nermin Zahide AYDIN

[30]Üzgel, İ. (2004), Batı Avrupa'yla İiş̧kiler, Türk Dış Politikası Kurtuluş Savaşı’ndan Bugüne Olgular, Belgeler, Yorumlar 1919-1980, C.I, İletişim Yayınlanı, (139-154), İstanbul.

[31]Villalta, J. B. (1982), Atatürk, Doğumunun 100. Yllında Atatürk Yayınları, Yonca Matbaası, Ankara.

[32] Yalçın, E. S. (2006), Mustafa Kemal Atatürk, Hayatı ve Eseri. Fersa Matbaacılık, Ankara. 